\title{
Socio-Economic and Psychological Determinants of Knowledge and Adoption of IPM Technology for Management of White Grub among the Farmers
}

\author{
R.D. Ahire, P.S. Kapse* and P.R. Deshmukh \\ Department of Extension Education, Vasantrao Naik Marathwada Krishi Vidyapeeth, \\ Parbhani-431 402 (M.S.), India \\ *Corresponding author
}

A B S T R A C T

\begin{tabular}{|c|}
\hline Keywords \\
\hline $\begin{array}{l}\text { Adoption, } \\
\text { Knowledge, } \\
\text { Correlation } \\
\text { Coefficient, IPM }\end{array}$ \\
\hline Article Info \\
\hline $\begin{array}{l}\text { Accepted: } \\
\text { 08 August } 2018 \\
\text { Available Online: } \\
\text { 10 September } 2018\end{array}$ \\
\hline
\end{tabular}

The present study was conducted in Marathwada region of the Maharashtra State with an objective to find out the relationship between socio-economic and psychological characteristics of the respondents with their knowledge and adoption of integrated management of white grub. The data was collected from the respondents by personally interviewing them with the help of the specially designed interview schedule. The data were analyzed with the help of frequency, percentage, standard deviation and coefficient correlation. The results revealed that majority of respondents were middle age group, educated upto middle school level, having medium level of annual income, small land holders, medium size of family, medium level of social participation, extension contact, availability of inputs of IPM, economic motivation, risk orientation and scientific orientation. The data further reported that the correlation coefficients depicted that most of independent variables viz., education, annual income, land holding, social participation, extension contact, family size, availability of inputs, risk orientation and scientific orientation were positively and significantly related with overall knowledge and adoption of integrated management practices of white grub.

\section{Introduction}

Integrated Pest Management (IPM) is defined as a system that in the context of the associated environment and the population dynamics of pest species utilizes all suitable techniques and methods in a compatible manner as possible and maintains the pest population at level, below those causing economic injury. In a more general sense, it applies to the co-ordinated management of all pest population in the agricultural environment. It is not simply the supreme position of control techniques such as chemical and biological control but the integration of all suitable management techniques with the natural regulating and limiting elements of the environment. Integrated management of pest technology emphasizes not only the reduction in use of pesticides and control the level of pest causing economic injury but also to facilitate the use of cultural, mechanical, biological and chemical methods of pest control. Thus it 
imply the farmers need to learn the principles of IPM technology and acquire the minimum knowledge and skill necessary to make selfdecision based on specific farm condition and discourage the indiscriminate use of pesticides. White grub is a polyphagous and nefarious pest of specific significance as it adversely affects crop productivity. It is rather difficult to eradicate this polyphagous and noxious pest because of its peculiar behaviour and nature of damage to the various crops. The pest can be managed effectively only by integration of several methods. It has threatened the crop production in the some districts of Marathwada region of Maharashtra state since 2016-2017. This pest had destroyed the crops from 30 to 80 per cent and in some cases 100 per cent and had created havoc among the farming community. So keeping in view the importance in rainfed farming, the present investigation was undertaken to study the socio-economic and psychological determinants of knowledge and adoption of IPM technology for management of white grub among the farmers with following objectives;

To study personal, socio-economic and psychological characteristics of the respondents.

To find out the relationship between personal, socio-economic and psychological characteristics of the respondents and knowledge about integrated management of white grub.

To find out the relationship between personal, socio-economic and psychological characteristics of the respondents and adoption about integrated management of white grub.

\section{Materials and Methods}

The present study was conducted in the Beed, Parbhani and Hingoli districts of Marathwada region purposely as heavy infestation of white grub were noticed on large area during the year 2016-17 and 2017-18. The data was collected from the respondents by personally interviewing them with the help of the specially designed interview schedule. From each district, four villages were selected randomly where severe out-break of white grub was observed. Thus total 12 villages were selected for the present study. Ten farmers from each of the selected villages were selected randomly, thus a sample size of 120 was selected for the study. The data were analyzed with the help of frequency, percentage, standard deviation and coefficient correlation.

\section{Results and Discussion}

\section{Personal, socio-economic and psychological characteristics of the respondents}

Table 1 indicates the personal, socio-economic and psychological characteristics of the respondents. The data reported that 61.66 per cent of the respondents were found in middle age group. Whereas 22.50 and 15.84 per cent of them were in old age and young age group, respectively. As per as education is concern, it was observed that 36.67 per cent of respondents had education upto middle school level.

Whereas 23.33 per cent of the respondents had education upto college level and 16.67 per cent of them were education upto higher secondary level, 10.83 per cent of them had education upto primary school and 10.00 per cent of them were illiterate. As regards to annual income, 83.34 per cent of the respondents were in medium income group (Rs. 90,584 /- to Rs.231616 /-) whereas 13.33 per cent of the respondents were having high income i.e. above Rs. 231617 /- and only 3.34 per cent of them were having low income i.e. below Rs. 90,583 /-. 
Table.1 Distribution of respondents according to their personal, socio-economic and psychological characteristics

\begin{tabular}{|c|c|c|c|c|}
\hline & & & & $\mathrm{N}=120$ \\
\hline Sr. No. & Characteristics & Score range & Frequency & Percentage \\
\hline (I) & Age & & & \\
\hline 1. & Young & (Upto 26 yrs) & 19 & 15.84 \\
\hline 2. & Middle & (27 yrs to $53 \mathrm{yrs})$ & 74 & 61.66 \\
\hline 3. & Old & (54 yrs \& above) & 27 & 22.50 \\
\hline (II) & Education & & & \\
\hline 1. & Illiterate & - & 12 & 10.00 \\
\hline 2. & Can read \& write & - & 03 & 02.50 \\
\hline 3. & Primary school & $\left(1^{\text {st }}\right.$ to $4^{\text {th }}$ Std $)$ & 13 & 10.83 \\
\hline 4. & Middle school & ( $5^{\text {th }}$ to $7^{\text {th }}$ std) & 44 & 36.67 \\
\hline 5. & Higher Secondary & $\left(8^{\text {th }}\right.$ to $10^{\text {th }}$ std $)$ & 20 & 16.67 \\
\hline 6. & College level & (above $10^{\text {th }}$ std) & 28 & 23.33 \\
\hline (III) & Annual Income & & & \\
\hline 1. & Low & (Up to Rs. 90,583/-) & 04 & 03.34 \\
\hline 2. & Medium & (Rs.90,584 to Rs.2,31,616/-) & 100 & 83.34 \\
\hline 3. & High & (Rs. 2,31,616/- \& above) & 16 & 13.33 \\
\hline (IV) & Land Holding & & & \\
\hline 1. & Marginal & (Up to 1 ha.) & 24 & 20.00 \\
\hline 2. & Small & (1.01 to 2.00 ha.) & 41 & 34.16 \\
\hline 3. & Medium & (2.01 to 4.00 ha.) & 21 & 17.50 \\
\hline 4. & Semi-Medium & (4.01 to 10.00 ha.) & 30 & 25.00 \\
\hline 5. & Big & (above 10.00 ha.) & 04 & 03.34 \\
\hline$(\mathbf{V})$ & Family size & & & \\
\hline 1. & Small & (Up to 3 members) & 18 & 15.00 \\
\hline 2. & Medium & (4 to 9 members) & 88 & 73.34 \\
\hline 3. & Big & (10 members \& above) & 14 & 11.66 \\
\hline (VI) & Social participation & & & \\
\hline 1. & Low & (Upto 1) & 43 & 35.83 \\
\hline 2. & Medium & (1.1 to 3.0$)$ & 51 & 42.50 \\
\hline 3. & High & (3.1 \& above) & 26 & 21.67 \\
\hline (VII) & Extension contact & & & \\
\hline 1. & Low & (Up to 3 ) & 30 & 25.00 \\
\hline 2. & Medium & (4 to 9$)$ & 70 & 58.33 \\
\hline 3. & High & (10 \& above) & 20 & 16.67 \\
\hline (IX) & Availability of inputs for IPM & & & \\
\hline 1. & Low & (Up to 1$)$ & 30 & 25.00 \\
\hline 2. & Medium & (2 to 6$)$ & 74 & 61.67 \\
\hline 3. & High & (7 \& above) & 16 & 02.00 \\
\hline$(\mathbf{X})$ & Economic motivation & & & \\
\hline 1. & Low & (Up to 16$)$ & 24 & 20.00 \\
\hline 2. & Medium & (17 to 24$)$ & 94 & 78.00 \\
\hline 3. & High & (25\& above) & 02 & 02.00 \\
\hline (XI) & Risk orientation & & & \\
\hline 1. & Low & (Up to 15$)$ & 19 & 15.83 \\
\hline 2. & Medium & (16 to 24$)$ & 93 & 77.50 \\
\hline 3. & High & (25\& above) & 08 & 06.67 \\
\hline (XII) & Scientific orientation & & & \\
\hline 1. & Low & (Up to 16$)$ & 21 & 17.50 \\
\hline 2. & Medium & (17 to 23 ) & 87 & 72.50 \\
\hline 3. & High & (24\& above) & 12 & 10.00 \\
\hline
\end{tabular}


Table.2 Relationship between personal, socio-economic and psychological characteristics of the respondents with their knowledge level

\begin{tabular}{|c|l|c|}
\hline Sr. No. & \multicolumn{1}{|c|}{ Independent Variables } & Correlation coefficient (r) \\
\hline 1. & Age & $0.036^{\mathrm{NS}}$ \\
\hline 2. & Education & $0.208^{*}$ \\
\hline 3. & Annual income & $0.203^{*}$ \\
\hline 4. & Land holding & $0.213^{*}$ \\
\hline 5. & Family size & $-0.118^{\mathrm{NS}}$ \\
\hline 6. & Family type & $-0.138^{\mathrm{NS}}$ \\
\hline 7. & Social participation & $0.262^{* *}$ \\
\hline 8. & Extension contact & $0.295^{*}$ \\
\hline 9. & Availability of inputs for IPM & $0.236^{*}$ \\
\hline 10. & Economic motivation & $0.032^{\mathrm{NS}}$ \\
\hline 11. & Risk orientation & $0.205^{*}$ \\
\hline 12. & Scientific orientation & $0.270^{* *}$ \\
\hline
\end{tabular}

*Significant at 0.05 level of probability

** Significant at 0.01 level of probability

${ }^{\text {NS }}$ Non significant

Table.3 Relationship between personal, socio-economic and psychological characteristics of the respondents with their adoption level

\begin{tabular}{|c|c|c|}
\hline Sr. No. & Independent Variables & Correlation coefficient (r) \\
\hline 1. & Age & $-0.071^{\mathrm{NS}}$ \\
\hline 2. & Education & $0.211^{*}$ \\
\hline 3. & Annual income & $0.369^{* *}$ \\
\hline 4. & Land holding & $0.279 * *$ \\
\hline 5. & Family size & $-0.069^{\mathrm{NS}}$ \\
\hline 6. & Family type & $-0.007^{\mathrm{NS}}$ \\
\hline 7. & Social participation & $0.272^{* *}$ \\
\hline 8. & Extension contact & $0.305^{* *}$ \\
\hline 9. & Availability of inputs for IPM & $0.276^{* *}$ \\
\hline 10. & Economic motivation & $-0.126^{\mathrm{NS}}$ \\
\hline 11. & Risk orientation & $0.289 * *$ \\
\hline 12. & Scientific orientation & $0.274^{* *}$ \\
\hline
\end{tabular}

*Significant at 0.05 level of probability

** Significant at 0.01 level of probability

${ }^{\mathrm{NS}}$ Non significant

The data further show that 34.16 per cent of the respondents were having small size of land holding ranging from 1 to 2 ha., followed by 25.00 per cent of them were having semimedium land holding and 20.00 and 17.50 per cent of the respondents were having marginal and medium land holding, respectively. With regards to family size, majority of the respondents $(73.34 \%)$ had medium size of family, while 15.00 per cent and 11.66 per 
cent respondents had small and big family size, respectively. It is revealed from Table 1 that most of the respondents $(42.50 \%)$ were having medium level of social participation followed by low level of social participation (35.83 \%), while 21.67 per cent of respondents were having high level of social participation. It is also noticed that majority of the respondents (58.33\%) had medium level of extension contact, followed by 25.00 per cent and 16.67 per cent of them had low and high level of extension contact, respectively.

As regards to availability of inputs required for integrated management of white grub, majority of the respondents $(61.67 \%)$ had medium level of availability of inputs, whereas 25.00 per cent of them had low level of availability and only 2.00 per cent of the farmers had high level of availability, respectively. With regards to economic motivation, majority of the respondents $(78.00 \%)$ had medium level of economic motivation, whereas 20.00 per cent of the respondents had low economic motivation and only 2.00 per cent of them had high economic motivation. It is also observed from Table 1 that 77.50 per cent of the respondents were in medium level of risk orientation, whereas 15.83 per cent and 6.67 per cent of the respondents were in high and low level of risk orientation, respectively. The data from Table 1 showed that 72.50 per cent of the respondents had medium level of scientific orientation. It was further reported that 17.50 per cent and 10.00 per cent of the respondents had low and high level of scientific orientation, respectively.

\section{Relationship between characteristics of the respondents and knowledge about integrated management of white grub}

The relationship between characteristics of the respondents and knowledge about integrated management of white grub is presented in Table 2. The data depicted that independent variables viz., education (0.208), annual income (0.203), land holding (0.213), social participation (0.262), extension contact (0.295), availability of input facilities (0.236), risk orientation (0.205), and scientific orientation $(0.270)$ were positively and significantly related with knowledge of the respondents about integrated management of white grub. Whereas age, family size and economic motivation had not shown any significant relationship with knowledge of the respondents about integrated management of white grub.

\section{Relationship between characteristics of the respondents and adoption of integrated management of white grub}

The data pertaining to correlation analysis between characteristics of the respondents and adoption of integrated management practices of white grub were presented in Table 3 . The correlation coefficients revealed that independent variables viz., education (0.211), annual income (0.369), land holding (0.279), social participation (0.272), extension contact (0.305), availability of input facilities (0.276), risk orientation (0.289), and scientific orientation (0.274) were positively and significantly related with adoption of integrated management practices of white grub. Whereas age, family size and economic motivation had not shown any significant relationship with adoption of integrated management practices of white grub.

These findings are in line with Chavan (2004), Girase et al., (2004), Zunjar (2011) and Sable (2012).

\section{References}

Chavan, A.M. 2004. Critical analysis of adoption behaviour of cotton grower 
towards IPM. Ph.D. (Agri.) Thesis, MPKV, Rahuri.

Girase, C.P., L.B. Kalantri and Tekale, V.S. 2004. Constraints faced by the farmers in the adoption of recommended package of practices of cotton. Asian J. Extn. Edu., XXII(1): 78-80.
Sable, B.D. 2012. Adoption of gap in IPM technology of cotton. M.Sc. (Agri.) Thesis, MKV, Parbhani.

Zunjar, R.P. 2011. Constraint faced by cotton growers in adoption of Integrated Pest Management. M.Sc. (Agri.) Thesis, MKV, Parbhani

\section{How to cite this article:}

Ahire, R.D., P.S. Kapse and Deshmukh, P.R. 2018. Socio-Economic and Psychological Determinants of Knowledge and Adoption of IPM Technology for Management of White Grub among the Farmers. Int.J.Curr.Microbiol.App.Sci. 7(09): 1201-1206.

doi: https://doi.org/10.20546/ijcmas.2018.709.142 